\title{
The Impact of Cézanne in Early Cubism
}

\author{
Enrique Mallen (Corresponding author) \\ Department of World Languages and Cultures, Sam Houston State University \\ United States \\ E-mail:mallen@shsu.edu
}

Received: November 13, 2021 Accepted: January 4, 2022 Published: January 5, 2022

doi:10.5296/ijch.v9i1.19195

URL: https://doi.org /10.5296/ijch.v9i1.19195

\begin{abstract}
The 1907 Salon d'Automne included a Cézanne retrospective. Comprising fifty-six of his works, most of them oils, it featured a group of late paintings, among them some nominally "unfinished." It had not been until his final years that the painter had begun to have wider public appeal. Now he had become the focus of attention of the avant-garde. Leo Stein recounted this transformation: "Hitherto Cézanne had been important only for the few; he was about to become important for everybody. At the Salon d'Automne of 1905 people laughed themselves into hysterics before his pictures, in 1906 they were respectful, and in 1907 they were reverent. Cézanne had become the man of the moment." And Picasso would say: "For us, Cézanne was like a mother who protects her children ... He was my one and only master ... I've spent years studying his pictures ... Cézanne! He was as you might say a father to us all. It was he who protected us." "2 The article explores the influence the Master of Aix had on both the Spaniard and his French colleague Georges Braque as they developed the ideas of what would become Cubism.
\end{abstract}

Keywords: Cézanne, passage, analytic, Cubism, cerebralization, creativity, generative

\section{Introduction}

Ten of Paul Cézanne's (b. 1839) works were still being displayed at the running Salon d'Automne when he died in Aix-en-Provence on October 22, 1906. ${ }^{3}$ Of the painter Daniel-Henry Kahnweiler, Picasso's dealer, had said: "[He is] the point of departure for all painting today."4 Both Matisse and Derain were Cézannists; each owned a work by him (which Picasso had seen in their studios). No doubt his death was the topic of conversation, and he must have become aware of the profound convergence of vision represented in the

\footnotetext{
${ }^{1}$ Baumann, Feilchenfeldt \& Gassner 2004, p. 182.

2 O’Brian 1994, 156; Richardson 1991, pp. 469-471; Richardson 1996, p. 52.

3 Torras 2002, 105; Daemgen 2005, 18; Daix 2007, p. 14.

${ }^{4}$ Kahnweiler 1949, p. 3.
} 
Salon between Cézanne and Gauguin, on the one hand, and the new generation of artists, on the other. ${ }^{5}$ Derain had moved to Montmartre, where he had taken the studio on rue Tourlaque (toward the bottom of rue Lepic) previously occupied by Pierre Bonnard, thus choosing Picasso's territory over Matisse's Quartier Latin. ${ }^{6}$ His defection from the older painter's group was the more opportune for coming at a time when Pablo was mustering all his resources to win out over his rival. Their frequent visits to each other's atelier were dictated less by friendship than by curiosity and competitiveness. Each had to see what the other was up to, and both of them would profit hugely from the dynamics of this rivalry. Derain would put his well-stocked mind at his disposal. His interests in philosophy, mysticism and comparative religion would be the more congenial to Picasso's in that they both tended toward the magical and the arcane. The Frenchman's notebooks and letters reveal that he had studied the Cabala, astrology, Pythagoras, Buddhism, the Tarot, Nietzsche, Plotinus, etc. ${ }^{7}$ Most importantly, he was deeply interested in African art, which he collected. ${ }^{8}$

\section{Gazing as an Operation of the Mind}

Of the master of Aix Picasso would say: "The reason why Cézanne was Cézanne is that he did concentrate: when he was confronted with a tree he looked hard at what was there before his eyes; he looked at it as hard as a man with a gun aiming at his quarry. If he fixed his eye on a leaf, he never let it go. And since he had the leaf, he had the branch. And the tree could never get away. Even if he only had the leaf, that was worthwhile. Often enough painting is no more than that ... You have to put all your concentration into it ... Oh, if only everyone could do just that!" 9 The Spaniard believed in two ways of seeing things, "the one by just looking at them and the other by gazing at them with real attention. Just looking is merely the eye's natural reception of the shape and likeness of the thing seen. Gazing with real attention is not only that but also an intense study of the means of acquiring a thorough knowledge of the object. So it might be said that what I call just looking is a physical operation and what I call gazing is an operation of the mind." 10 Cézanne likewise wanted to "graph the very fluctuations of seeing." Eventually, Cubism would propose that the work of art was itself a reality that represented the very process by which nature is transformed into art. In the new world it created, no fact of vision remained absolute, thus expressing an awareness of the paradoxical nature of reality and the need for describing it in multiple and even contradictory ways. ${ }^{11}$ Adolphe Basler has traced what he calls the "cerebralization" of modern painting to Cézanne. Up to the beginning of the century, the artist used to paint more or less as he saw; since then he has begun to paint as he conceives. Picasso was destined to complete the cerebralization of art in his time. ${ }^{12}$

Through October 15, Cézanne's letters to Emile Bernard were published in the Mercure de

\footnotetext{
5 Daix 2007, p. 14.

${ }^{6}$ Richardson 1996, p. 72; also Franck 2001, p. 65; Unger 2018, p. 297.

7 Richardson 1996, p. 74.

8 Franck 2001, pp. 65-66.

9 O’Brian 1994, p. 168.

10 Kozloff 1973, pp. 18-26.

11 Rosenblum 1976, pp. 13-14.

12 Vallentin 1963, p. 79.
} 
France, notably the famous one dated April 15, 1904: "Allow me to repeat what I told you here: handle nature through cylinders, spheres, cones, all placed in perspective ... Lines perpendicular to this horizon provide depth. And nature, for we humans, is more a question of depth than surface."13 When Braque went to L'Estaque around this time, his style underwent a major change, having also seen the retrospective. "I realized that the exaltation that had overwhelmed me during my first visit [to the Midi] and which I had transmitted onto canvas was no longer the same. I saw that there was something further. I had to cast around for another means of self-expression more in keeping with my nature." 14 He would paint his first conception of Le viaduc de l'Estaque before returning to Paris in late October or early November. He and Pablo studied Cézanne in a more or less constructive fashion. That is to say, they seized on an element of structural and formal strength in his work, which they saw as a corrective to the formlessness that had characterized so much French painting since the Impressionists had insisted on the validity of an instantaneous form of vision, which had so often dissolved the solidity of the material world into a haze of atmospheric color and light. They saw, too, in his obvious concern with purely pictorial problems an antidote to the emotionalism and decorative symbolism of so much other post-Impressionist painting. ${ }^{15}$

The effect Cézanne was having in his work is most evident in the major oil he was working on at this time: Trois femmes. ${ }^{16}$ When Gertrude and Alice visited the Bateau-Lavoir on October 9 or 10, they saw the canvas still in its early stages: "Against the wall was an enormous picture, a strange picture of light and dark colors, that is all I can say, of a group, an enormous group and next to it another in a sort of a red brown, of three women, square and posturing, all of it rather frightening." 17 Their description ${ }^{18}$ corresponds to contemporaneous photographs showing Les demoiselles d'Avignon ${ }^{19}$ and also, more or less concealed next to early, the "primitivist" state of Trois femmes. The latter would become the most ambitious Negro painting of this period. From first to last it remained a distinctly sculptural painting, with the accent on projecting volumes, solid mass, weight and gravity rather than surface decoration. When reworking the faces, Picasso somewhat toned down the allusion to tribal masks. One motive was, presumably, to unify the heads and bodies and create a more harmonious ensemble. The women were to be primitive dryads rather than accusing and commanding idols. Aside from the generalized debt to masks, the main reference to tribal art is through the imitation of techniques of woodcarving. ${ }^{20}$

According to Steinberg, the canvas represents the sexes struggling for definition. The central figure is androgynous, a creature yearning for sexual identity, which comes to fruition on the two figures at right and left. The blank eyes signify a lack of self-awareness; the "masks" are

\footnotetext{
13 Golding 1968, p. 64; Richardson 1996, p. 50; Baldassari 2007, p. 335; Roe 2015, p. 204; Unger 2018, p. 353.

14 Richardson 1996, p. 68.

15 Golding 1968, p. 65.

16 Trois femmes. Paris. [Fall-Late] [End/1907-] Spring-Summer [-Fall]/1908 [-January/1909]. Oil on canvas. 200 x $178 \mathrm{~cm}$. The State Hermitage Museum, Saint Petersburg. OPP.08:009.

17 Stein 1961, pp. 20-22; Cousins \& Seckel 1994, p. 154.

18 Richardson 1996, p. 57.

19 Les demoiselles d'Avignon. Paris. [Late-March] June-July/1907. Oil on canvas. 243,9 x 233,7 cm. The Museum of Modern Art, NYC. (Inv 333.1939). Acquired through the Lillie P. Bliss Bequest. OPP.07:001.

${ }^{20}$ Cowling 2002, pp. 115-194.
} 
a sign for the "primitive" in the sense of a primordial substance that gives birth to sexual difference. The striving of the side figures deforms them, allowing them to emerge from an undifferentiated origin in the center of the composition into their separate identities. The energy of the struggle is that of libido, a sexual energy. Picasso asserts through his painting that the form demanded by a different kind of human figure cannot be subsumed within a homogenizing painting procedure (like Cézanne's), and that it must be achieved by absorbing only certain aspects of his practice (in the merging of planes that make up the composition) and blending them with alternative forms of figuration. In the critic's words, "he was resisting Cézanne." ${ }^{21}$ However, although tribal sculpture would continue to play a covert psychic role in his art, Cézanne progressively dictated Pablo's choice of subjects and, to some extent, his syntax." ${ }^{22}$ Most of his contemporaries, including his closest friends and fellow artists, had dismissed Les Demoiselles as a monstrous aberration, a bizarre experiment gone awry. To them, the grafting of Africanized elements on to primitive Iberian figures seemed incoherent and unresolved, or simply downright grotesque. Picasso realized that in his next major canvas he needed to achieve the degree of pictorial integration and unity that the previous work lacked. The exhibition of ten paintings by Cézanne in the 1906 Salon d'Automne, following the artist's recent death, and the full-scale retrospective at the recent Salon d'Automne had convinced him to make the decisive move. ${ }^{23}$

Work on the large canvas was concurrent with a series of gouaches and drawings Picasso executed late in the year, where he transformed Cézanne bathers into a frieze of hybrid women, naked except for a towel or two, and striking physique-contest poses, setting them off against a vault of trees on the bank of a river or lake, indicated by the front of a boat in the immediate foreground. In the interest of tension, unity and drama, he soon abandoned the horizontal format and over the next six months chopped up the picture into component parts: monumental threesomes, homogenized couples and androgynous single figures with raised elbows. ${ }^{24}$ In works like Trois femmes: $n u$ debout (Étude), ${ }^{25}$ we run into what Kahnweiler called "the mad audacity with which Picasso grappled with all problems simultaneously." The abandonment of perspective, the conquest of space by the fractioning of planes, heavily outlined flat tones or hatching. ${ }^{26}$ We find yet another major bid to synthesize the sexes, as he scaled up the figure into a monumental androgyny with a mandorla shaped diaphragm that stands for both phallus and vagina. As Richardson asserts, he wanted to inaugurate a new human race - native of no identifiable place. "They would be his own Frankensteins: a bit of this and a bit of that, and by virtue of being outside time and place and even gender, they would be instrumental in establishing primitivism as the look of modernism." ${ }^{27}$

The compositions became engulfed in obsessive graphic rhythms, strong color contrasts, and stylization pushed to the point of abstraction. This resulted in monumental nudes, often set in

\footnotetext{
21 Steinberg 2007, p 79; also Cox 2010, pp. 92-93.

22 Richardson 1996, p. 57.

${ }^{23}$ Christie's 2007, cat. no. 0049, 1900.

${ }^{24}$ Richardson 1996, p. 55.

25 Trois femmes: nu debout (Étude). Paris. Winter/1907-1908. Pen \& black ink on handmade paper with cardboard backing. 31,5 x 23,7 cm. Staatsgalerie Stuttgart. (Inv C 59/889). Graphische Sammlung. OPP.07:333.

26 Daix 1965, p. 71.

27 Richardson 1996, p. 56.
} 
imaginary forests. He was in fact looking for a system of construction, a spatial organization of the composition, which did not depend on any external scaffolding, nor on illusionist tricks, but on the authentic expression of the intrinsic qualities of the figures and on the arrangement of the physical qualities of paint on canvas, on lines of force and how color appears to the eye. As Liliane Brion-Guerry has argued, it was not just preoccupation with the constructive expression of the figures which created the spatial unity, but the fact that space itself became an integral part of the construction. ${ }^{28}$

\section{Striving for Pictorial Synthesis}

Early in 1908, Georges and Pablo were constantly in each other's company, exploring rather than denying the similarities in their work. Both were striving for a pictorial synthesis, moving away from mimesis and aiming for the creation, rather than simply the illustration, of an experience on canvas. ${ }^{29}$ Braque was at work on Le grand $n u$, which he would complete in mid-March, just before the opening of the Indépendants. ${ }^{30}$ Daily contact between them seems to have had the effect of making the mercurial Spaniard work in a more methodical and consistent fashion, building upon previous achievements, rather than setting off suddenly on a new tack. A gradual but inexorable shedding of the illusion of perspective, solidity and fixed identity occurred as he pressed on with his investigation of the limits and potential of his "analytical" style. Apollinaire later wrote: "A man like Picasso studies an object as a surgeon dissects a cadaver." 31 These renewed efforts would mark the next stage of Trois femmes. Picasso had seen in the Salon des Indépendants Derain's La Toilette which depicted three nudes, and Braque's Le grand nu, which combined three different views of a nude woman. All three artists seemed to be vying for the honor of being seen as Cézanne's successor, and Pablo was once again eager to resume his painting in a Cézannian manner, that is, through the treatment of volume by means of modeled planar forms. He would continue to work on the painting until well into the fall, with another hiatus during the summer. ${ }^{32}$

That spring, Picasso painted a number of still lifes- the oils Bols et cruche (Cruche, bol et compotier $)^{33}$ and Carafe et trois bols, ${ }^{34}$ and the gouache Bol vert et tomates. ${ }^{35}$ In them, hatchings rapidly yielded to a direct presentation of objects in the round. By their very simplicity the items collected on the table anticipated the reign of humble daily life which was soon to prevail: glasses, bowls and bottles seen from above. They, however, had acquired a new solidity and seemed to be carved in wood, even those which their color revealed to consist of metal or glass. Objects formed a compact mass, obscuring one another "as though

\footnotetext{
28 Daix 1979, pp. 47-48.

${ }^{29}$ Roe 2015, p. 234.

${ }^{30}$ Cousins \& Daix 1989, p. 349.

${ }^{31}$ Cowling 2002, pp. 201-217.

32 Christie's 2007, cat. no. 0049, 1900.

33 Bols et cruche (Cruche, bol et compotier). Paris. Spring/1908. Oil on canvas. 81,9 x 65,7 cm. Philadelphia Museum of Art. (Inv 1952.61.93). A. E. Gallatin Collection. OPP.08:002.

${ }^{34}$ Carafe et trois bols. Paris. [Spring-] [Summer]/1908. Oil on cardboard. 66 x 50,5 cm. The State Hermitage Museum, Saint Petersburg. (Inv 8986). OPP.08:032.

${ }^{35}$ Bol vert et tomates. Paris. Spring-Summer/1908. Tempera on wood panel. 20,6 x 26,9 cm. Christie's. \#507, 6146, 06/30/99. OPP.08:260.
} 
to prevent the air from circulating." ${ }^{36}$ For the third work, the influence of the master of Aix is especially evident in the strong palette and the dynamic execution. The deeply saturated and dark-valued pigments give the work a rich tonality and strong plasticity. Picasso had been particularly impressed by the creative force of the Frenchman's active brushwork. ${ }^{37} \mathrm{He}$ said: "As soon as Cézanne begins to make the first stroke, the picture is already there." 38

In the first oil, the compote with the perfunctorily painted four green apples retained its own identity, albeit its pedestal appears carved rather than modeled and placed on a flat piece of cardboard as its base. Rosenblum comments about this painting: "Strange elisions of planes, contradictory light sources, autonomous patterns of brushwork - such devices compress these volumes into a shallow space in which adjacent planes are interlocked in a nervous shifting of concave and convex surfaces that undermines the effects of traditional chiaroscuro and perspective." 39 In the second oil, the light from a hanging lamp makes the bowls look round. The contrast of colors - orange, red, black, grey - was somewhat less hallucinatory. At the same time, it did not lack its mysteries, as the orange bowl in the background, for example, loomed up behind the carafe. One enigmatic element was the contrast between that pivotal container, which was enclosed by the cup placed delicately on top of it, and the ellipses of the other four vessels, all open and all empty. ${ }^{40}$ The viewpoint clearly derived from Cézanne's perspective, ${ }^{41}$ but what perhaps distinguishes it was Picasso's anxiety to keep open the collapsed intervals between objects that tend to upstage one another. Although the four vessels and the wayward shadows they cast were arrayed to trace a continuously looped surface rhythm, viewed in recession, they stood apart. Cups, bowl, and bottle, each had its contour lifted off from the form behind, either by dint of shadow or by a warm atmospheric glow; not like Cézanne's all-enveloping air, but as directed air circulating in staggered intervals in the spaces between. ${ }^{42}$

That season he also worked on figure compositions. In Femme à l'éventail, ${ }^{43}$ with her white shift, rigid pose and throne-like seat, the life-sized figure seems like a priestess withdrawn in profound meditation, and since the viewpoint demands that we look up at her, we are bound to feel overawed. Cowling points out that the mask-like head, conceptualized anatomy and geometric treatment of the throne allude to an African Fang sculpture. Counterbalancing these allusions, the white shift and one uncovered breast are unmissable references to Greco-Roman reliefs and statues of Ariadne, the Bacchantes and other erotic heroines. Invoking the irrational "Dionysiac" strain in classical culture justified the merging of the classical and the tribal. ${ }^{44}$ It might have been the impact of Matisse's Baigneuses avec une tortue that contributed to Pablo's abandonment of primitivist excesses. He was constantly

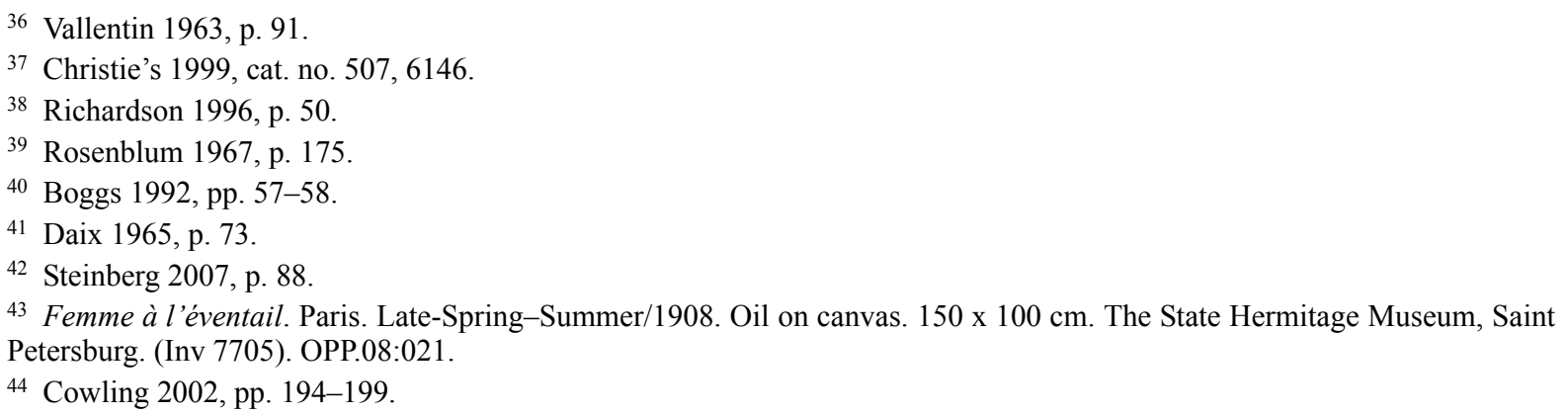


refining his primitivism, converging with the timelessness of Cézanne, whom he constantly kept in his sight. ${ }^{45}$

Buste de femme accoudée (Femme dormante) ${ }^{46}$ represents a nude woman half-length, upright, asleep and in stark proximity to the viewer. She is depicted in the sparest economy of graphic means: black contour lines, mostly straight, overlapping, with color held down to a minimum. The concentration on a single device - rigid rods crossing over and under-is astonishing in its effective evocation of mass. As Steinberg maintains, if Picasso was at this moment undergoing the influence of Cézanne, then he must have seen his painting take the opposite course, that is to say, toward a system which questioned the very reality of overlappings. The painting must then be read as "sheer recalcitrance." 47

\section{Structural Aspects of the Subject}

After May 2 and the closing of the Salon des Indépendants, Braque recovered his paintings, and before June 1, went to L'Estaque, a small port in the vicinity of Marseille where Cézanne had once worked, ${ }^{48}$ in order to help organize the upcoming show of the Cercle de l'Art Moderne, which would open in June. ${ }^{49} \mathrm{He}$ would remain there until early September. ${ }^{50}$ While in Provence, he executed a series of landscape paintings utilizing Picasso's still unfinished Trois femmes's model of faceted, interlocking forms, arranged in a shallow space like that of a bas-relief. ${ }^{51} \mathrm{He}$ would later tell Dora Vallier: "I found that the exaltation that had overwhelmed me on my first visit, and which I put into my [fauve] pictures, was no longer the same." 52 He abandoned the last vestiges of wild coloring and limited the palette to a Cézannesque gamut of viridian, ochers, grays and blacks. It was by composition alone that he now started to reveal the structural aspects of the chosen subject. He managed to shape the volumes through the shimmer of his brushstrokes, thereby appropriating an overlooked (or poorly observed) Cézannist technique. ${ }^{53}$

On May 26, Pablo wrote to the Steins in Fiesole, and told them that work on Trois femmes was progressing. Although he was still using hatching and primitivist deformations, African elements in his work were receding in favor of relief effects influenced by Cézanne, probably related to Braque's Cézannist reductivism of Le grand $n u$, which he must have seen before his friend's departure. ${ }^{54}$ His work on the large composition had been painfully slow and disappointing. He had completely repainted it each time he turned to it. He was at the same

\footnotetext{
45 Daix 2007, pp. 23-24.

46 Buste de femme accoudée (Femme dormante). Paris. Late-Spring-Summer/1908. Oil on canvas. 81,2 x 65,4 cm. The Museum of Modern Art, NYC. (Inv 575.70). Acquired by exchange from Galerie Beyeler, Basel, in 1970, through the Katherine S. Dreier Bequest, and the Hillman Periodicals, Philip Johnson, Miss Janice Loeb, Abby Aldrich Rockefeller, and Mr. and Mrs. Norbert Schimmel Funds. OPP.08:111.

47 Steinberg 2007, p. 87.

48 Richardson 1996, p. 97. Others date the trip to summer (Unger 2018, p. 361).

49 Among the other exhibiting artists were Derain, Dufy, Friesz, Marquet, Matisse, van Dongen, and Vlaminck (Roe 2015, 234).

50 Cousins \& Daix 1989, pp. 352-353.

51 Karmel 2007, p. 152.

52 Richardson 1996, p. 97.

53 Daix 2007, pp. 22-23.

${ }^{54}$ Cousins \& Daix 1989, p. 352; Baldassari 2007, p. 336.
} 
time working on other studies of nudes, perhaps in the hope that they would help to clarify and resolve some of the issues that had blocked his ability to finish the canvas. If the project had owed its initial theme and some of its characters to Cézanne, the debt in the subsequent version would be even more substantial: a faceted surface with no recessed intervals and no gaps; figures and ground near homogeneous; broken planes set off by minor chromatic or tonal shifts; and a compression of the depth of field to give that illusion of bas-relief which deploys nothing but fronts. ${ }^{55}$

Looking at the late Cézanne bathers, Picasso was also considering the integration of the figure within a more open scenery. During that spring and early summer he painted a series of imaginary landscapes like Paysage, ${ }^{56}$ which shows him breaking down the background, reducing it to a bare and expressive minimum. He gave the landscape an almost faceted appearance through which to convey a sense of three-dimensionality. In this he appears to pay homage once again to the master of Aix, taking his earlier experiments to a new extreme. ${ }^{57}$ In Paysage ${ }^{58}$ he translated the figural forms into a densely wooded scenery, filled with twisted, thorny and impenetrable forms, which may reflect the impasse at which he had arrived in his large figure composition. ${ }^{59}$ This Dantesque setting may allude to a tragic incident on June 1, in which the young German painter Karl-Heinz Wiegels, with whom Pablo and Fernande were very close, killed himself while in a drug-induced delirium. ${ }^{60}$ He had seen his friend's body dangling in the window, which became a nightmarish vision he would never forget. His death so frightened him that he resolved to change his ways. She wrote: "Once in a while we would go back to taking opium. We did this until a tragedy unfolded before our eyes, until, that is, our neighbor the German painter Wiegels committed suicide. After an eventful evening during which he had successively taken ether, hashish, and opium, he failed to recover his sense, and in his madness hanged himself a few days later in spite of the care with which we looked after him. This taught us a lesson, and being very shaken up, we decided never to touch drugs again." ${ }^{61}$ The jagged, shard-like forms in the gouache are remarkably and uniquely expressionistic - there is an almost tormented sense of awareness that compels the artist to become one with the landscape. "I want to see my branches grow," he told Malraux. "That's why I started to paint trees; yet I never paint them from nature. My trees are myself." ${ }^{2}$ Olivier added: For some time the studio where he had died became a place of terror for us, and the poor man appeared to us everywhere, hanging as he had been the last time we ever saw him." ${ }^{93}$ Nature morte à la tête de mort, ${ }^{64}$ completed in

\footnotetext{
55 Steinberg 2007, pp. 75-76.

56 Paysage. Paris. [Spring/1908]. Gouache \& charcoal on thick beige paper. 47,6 x 61,6 cm. The Metropolitan Museum of Art, NYC. (Inv 2014.464). Leonard A. Lauder Cubist Collection, Purchase, Leonard A. Lauder Gift, 2014. OPP.08:352.

57 Christie's 2007, cat. no. 0120, 1902.

58 Paysage. Paris. Spring-Summer/1908. Gouache over pencil on panel. 26,9 x 21,2 cm. Christie's. \#48, 1900, 11/06/07. OPP.08:155.

59 Christie's 2007, cat. no. 0048, 1900.

60 Richardson 1996, p. 87; Daix 2007, p. 24; Baldassari 2007, p. 336; Caruncho \& Fàbregas 2017, p. 70.

61 Olivier 2001, p. 216; also Roe 2015, p. 239.

${ }^{62}$ Richardson 1996, p. 93.

${ }^{63}$ Olivier 2001, p. 216.

${ }^{64}$ Nature morte à la tête de mort. Paris. Summer-Fall/1907 [-Spring/1908]. Oil on canvas. 116,3 x $89 \mathrm{~cm}$. The State Hermitage Museum, Saint Petersburg. (Inv 9162). OPP.07:008.
} 
late spring, was also possibly painted to commemorate Wiegels's death. ${ }^{65}$

Nu appuyé (Femme étendue ${ }^{66}$ from this same period belonged to a project for two bathers, one standing and one reclining, against a forest background Vue du lac entre deux baigneurs (Etude). ${ }^{67}$ What attracted him most about this motif was, on the one hand, the sculptural sense of mass and weight that gave the ungainly bodies such a potent physical presence, and on the other the oppressive intensity of mood, the sense of an internalized drama that we also saw in the previous works. Cézanne's example aided the understanding, absorption and integration of the lessons of art nègre because it was felt there were conceptual and structural affinities between the rough-hewn geometry, arbitrary anatomy and rugged monumentality of his late figure style and the conventions of certain types of tribal carving. Picasso's own hatched brush marks simultaneously allude to both the grooved, grainy surfaces of primitive wood carvings and to the master's so-called "constructive" stroke. ${ }^{68}$ Unlike the abstract faceting of the more Cézannesque nudes mentioned earlier, the forms here were relentlessly sculptural, while the strong emphasis on the mass of the individual body parts was clearly indebted to the imaginative restructurings of the human figure in Negro art. With its bulging musculature, spherical head and breasts, and the exaggerated torsion of its pose, the figure also recalled Matisse's $\mathrm{Nu}$ bleu (Souvenir de Biskra), itself a fusion of European and African influences, which had scandalized the public and bewildered the critics at the Salon des Indépendants the previous year. ${ }^{69}$ He was juxtaposing his work with his.

Matisse was on a trip to Germany with Hans Purrmann, his first one to that country. ${ }^{70}$ Meanwhile Derain was spending the summer at Martigues, where Vlaminck later joined him. On arrival at Marseilles, the latter was revitalized, enchanted by the sight of the old harbor, bathed in light: "It seemed as though everything was seen through a silken gauze ... The rosy blue rings, touched with gold, made me think of some immaterial world ..." What would become Cubism was gradually separating the artists into different camps: it would set Picasso apart not only from Matisse, but also from Derain and Vlaminck. By contrast, his collaboration with Georges would deepen. The two artists continued to work intensively, both separately and together, to sharpen their perceptions and see how far it could possibly take them. ${ }^{71}$ Braque had rented a room at Hotel Maurin in L'Estaque for the summer. Although just twenty kilometers from Martigues where Derain was staying, the artistic distance between them had increased. Of Cézanne's effect on him Braque later declared: "It was more than an influence, it was an initiation. Cézanne was the first to have broken away from erudite, mechanized perspective ..." During his sojourn there, he would execute a series of "full-blown Cubist landscapes" including Maisons à l'Estaque, marking his complete

\footnotetext{
65 Cousins \& Daix 1989, p. 353.

${ }^{66} \mathrm{Nu}$ appuyé (Femme étendue). Paris. [Spring]/1908. Gouache on wood. 21 x $27 \mathrm{~cm}$. Christie's. \#13, 3442, 11/04/13. OPP.08:017.

${ }^{67}$ Vue du lac entre deux baigneurs (Étude). Paris. Summer/1908. Pen, ink, gouache \& label stuck on on cardboard. 45,5 x 26 $\mathrm{cm}$. Hilde Thannhauser Succession, Bern. OPP.08:121.

${ }^{68}$ Cowling 2002, pp. 194-199.

${ }^{69}$ Christie's 2013, cat. no. 13, 3442.

70 Cousins \& Elderfield 1992, p. 181.

71 Roe 2015, p. 248.
} 
departure from Fauvism. ${ }^{72}$

While many of contemporary historians and critics saw a direct connection between Cubism and Fauvism, this existed only in the most general interpretation. A tendency to take greater liberties with visual appearances was the only very broad sense in which Fauvism foreshadowed the later movement. Cubism, on the other hand, led to greater abstraction due to the fact that the vision of those who implemented it was conceptual and intellectual rather than physical and sensory. ${ }^{73}$ In this they followed Cézanne, who apart from emphasizing the two-dimensional plane on which he was working, by tipping forward certain objects, he also gave the impression that he was adopting variable or movable viewpoints, thus synthesizing into a single image the information gathered from looking at things from successive viewpoints, as Golding explains. ${ }^{74}$

Indeed, the older painter had found himself torn between two apparently irreconcilable poles: on the one hand the fragmentary and inconstant nature of the visual perceptions he trusted so passionately; and on the other, his ambition for an art that had constancy and a composite finality. He realized that painting had to be a question of the eye and the brain working together to organize visual sensations into a coherent, permanent structure. It consisted of seeking the expression of what one knows, in organizing perception into a personal aesthetic. Equally, Picasso was quoted as saying: "Nature and art being two different things cannot be the same thing. Through art we express our conception of what nature is not."75 We can think of modernism itself as a gradual split in the connection between representation and its referent. And yet, as Krauss indicates, there was an expressed concern that abstraction, trafficking in the token as an utterly empty sign, might lead to language that means nothing at all, to an emptying out of meaning, signs circulating without a "convertible" base in the world of nature. ${ }^{76}$ Picasso always denied that his painting was abstract.

As late summer approached, Pablo postponed any plans to a trip to Spain to continue working on Trois femmes. He overpainted the lateral faces in a black linear mode, divergent not only from Braque and Cézanne but, more pertinently, from the original state still visible in some sections. In the process, he produced once again, as in Les demoiselles d'Avignon, a disruptive internal mutation. Steinberg argues that this was intentional. He was struggling with a world that was not his. An artist like him, whose possessive sight must grapple the thing it sees, demands complementary selves in responsive embodiment. Cézanne's method, therefore, may have struck him as a threat to his own field of action; "it abrogated the very conditions that made the world fit for contest, encounter, embrace. ${ }^{77}$ The weather was stiflingly hot and the Bateau-Lavoir an oven. Pablo, who suffered from the heat, often worked naked; and Fernande also went around in little more than a shift. ${ }^{78}$ So it is no wonder that physical contact was in his mind. In the end, however, Cézannism would prevail.

\footnotetext{
72 Cousins \& Daix 1989, p. 353.

73 Golding 1968, pp. 16-17.

74 Golding 1968, pp. 69-71.

75 Wadley 1970, pp. 29-30.

${ }^{76}$ Krauss 1998, pp. 6-18.

77 Steinberg 2007, pp. 79-80, 83-84.

78 Richardson 1996, p. 87.
} 
Throughout the summer, Picasso turned more and more toward that direction. The paintings he executed evoked the tranquility of the remote riverside farmland on La-Rue-des-Bois where he had temporarily relocated with Fernande. No cafés, or shops or sights to see, not even a road junction, just ten non-descript houses and barns scattered either side of a country road. Nature invaded his canvases, a dark green saturated with gold and harmonizing with the warm, russet tone which he was using. ${ }^{79}$ In the oils Maisonette dans un jardin (Maisonnette et arbres) ${ }^{80}$ and Paysage: La Rue-des-Bois, ${ }^{81}$ he was more interested in mass than space, and at first he practiced passage only insofar as it enabled him to homogenize and amplify the massiveness of his figures. ${ }^{82}$ In the second canvas, the composition is structured by the lines of the tree branches that frame a view of the landscape beyond. "Nature should be rendered as cylinders, spheres, cones, and the whole put into perspective," Cézanne had written. Accordingly, in the center of the painting there is a mass of very strongly modelled geometric volumes - most likely rocks - that have not been set off by outlines, but that have been built up only with colors that seem to project their own light. ${ }^{83}$ Since he could never depict anything without to some degree identifying with it, he assumed the role of genius loci in these landscapes, investing the trees with his own life force, as if he were reinventing the universe in his image. ${ }^{84}$

In Maisonnette dans un jardin, ${ }^{85}$ he reduced the subject, restraining it to contrasts between the geometry of houses and the curvilineal trees in the surroundings, which he also reduced to their basic structure. These landscapes are airless; volumes fill them to the point of giving the impression they are about to overflow. Here again, the contrasts between the geometrical buildings and the rhythmic vegetation displayed frequent transitional gaps, recalling Cézannian passages. ${ }^{86}$

The presence of Cézanne would also be felt in some of the still lifes. In Vase de fleurs, verre de vin, et cuillère, ${ }^{87}$ the colors of the flowers seldom break beyond the greens, rose, and grays of the rest of the painting except in a sporadic touch of yellow. The background was a cold gray, and the top of the table was slightly bent, only vaguely of a copper tone. So as to mark his kept allegiance, the furniture features a conspicuous drawer that reminds us of Cézanne, who had often included that element in his still lifes. ${ }^{88} \mathrm{He}$ had spent time absorbing the lessons of the old master. Objects were approached with certain "pre-existent ideas" of form, but they still played a major role in the structuring of the composition. There was a

\footnotetext{
79 Vallentin 1963, pp. 92-94; Palau i Fabre 1990, pp. 104-106; Richardson 1996, p. 93.

${ }^{80}$ Maisonette dans un jardin (Maisonnette et arbres). [La Rue-des-Bois] [Paris]. [Early-August/1908 [-Early/1909]. Oil on canvas. 92 x $73 \mathrm{~cm}$. The Pushkin State Museum of Fine Arts, Moscow. (Inv 3350). OPP.08:013.

${ }^{81}$ Paysage: La Rue-des-Bois. La Rue-des-Bois. Early-August [September] $/ 1908$. Oil on canvas. 100,8 x 81,3 cm. The Museum of Modern Art, NYC. (Inv 1413.74). Gift of David and Peggy Rockefeller, 1974. OPP.08:007.

82 Richardson 1996, p. 97.

83 Seckel 1996, p. 32.

84 Richardson 1996, p. 93.

${ }^{85}$ Maisonnette dans un jardin. La Rue-des-Bois. [Late-Summer-Early-Fall] August/1908. Oil on canvas. 73,6 x 60,5 cm. The State Hermitage Museum, Saint Petersburg. OPP.08:005.

${ }^{86}$ Daix 2007, p. 26.

87 Vase de fleurs, verre de vin, et cuillère. La Rue-des-Bois. [Fall] August/1908. Oil on canvas. 81 x $65 \mathrm{~cm}$. The State Hermitage Museum, Saint Petersburg. (Inv 8999). OPP.08:008.

88 Boggs 1992, pp. 60-61.
} 
"logic." but there was also an object to which the logic had to be applied. ${ }^{89}$ Other works like Nature morte au bouquet de fleurs ${ }^{90}$ resonated with the geometric forms and earthy tones that had dominated the Frenchman's more mature paintings. Remarkable in it is an early inclination to simplify and detach the shadows cast by objects on the surfaces, presaging the particular use of passage, that would characterize the high Cubist still life several years later. $^{91}$

While in La Rue-des-Bois, he was particularly taken with the hulking form of their landlady, a woman of mythic proportions - over six feet tall and weighing almost three hundred pounds - known as Madame Putman. He painted her multiple times in oils like La fermière: buste ${ }^{92}$ and La fermière en pied. ${ }^{93}$ In the latter, her hands hang massively while enormous biceps protrude to the sides. She looks like a primitive effigy seemingly hacked out of wood. The orange-brown skin stands out against a green background. ${ }^{94}$ Her head is treated as a columnar extension of her thick neck, her face flat as the sawn-off stump of a tree, onto which minimal features - a tiny wedge of a nose, vestigial eyes (no mouth) — have been grafted. In her blue dress, she seems immutable, impossible to uproot, like a spirit of the soil. The upward angling of the face derived from the tribal formula he had used before, but the style now suggests the influence of Cézanne. ${ }^{95}$

The human figure has always played a much more important part in the work of Picasso than in that of Braque, and the Spaniard looked with particular interest at Cézanne's figure work. What seems to have fascinated him about the painter's figure studies and portraits, besides his obvious interest in their structural formal properties, is the complete neglect of details, which was at times extended even to a disregard of the individual facial features. Oddly, this was mixed with an extremely elaborate build-up of form in terms of small flat planes based on empirical observation, which, following countless adjustments, fuse into the whole and become inseparable from each other. ${ }^{96}$ For the artist, the painting became the expression of a stylized world, filled to overflowing with bulky volumes, an airless world in which distances were compressed as by a telephoto lens, unfolded and came alive before our eyes. Picasso emulated his technique of redistributing the real volumes in his picture in terms of the formal demands of the composition. Henceforth, the intellectual organization of the canvas had the last word. ${ }^{97}$

As he built his compositions, he was faced with a dialectic between his own vehemence, his violent impulses, and his urge to understand what he painted, because painting after all was

\footnotetext{
89 Gray 1953, pp. 51-54.

90 Nature morte au bouquet de fleurs. La Rue-des-Bois. [Summer] August/1908. Oil on canvas. 38,2 x 46,5 cm. Sotheby's. \#27, N09219, 11/04/14. OPP.08:145.

91 Sotheby's 2014, cat. no. 27, N09219.

${ }^{2}$ La fermière: buste (Madame Putman). La Rue-des-Bois. [Summer] August/1908. Oil on canvas. 81,2 x 65,3 cm. The State Hermitage Museum, Saint Petersburg. (Inv 6531). Acquisition 1930. OPP.08:123.

${ }^{93}$ La fermière en pied. La Rue-des-Bois. [Late-Summer-Early-Fall] August/1908. Oil on canvas. 81,5 x 65,5 cm. The State Hermitage Museum, Saint Petersburg. (Inv GE.9161). Acquisition 1948. OPP.08:004.

94 Vallentin 1963, p. 93.

95 Richardson 1996, p. 94; Roe 2015, p. 243.

96 Golding 1968, p. 72.

${ }^{97}$ Daix 1979, pp. 50-53.
} 
for him a form of mental computation, involving his whole intelligence as well as his keen sensitivity. What interested him, as can be seen from his sketchbooks, was to clarify the devices whereby an image was constituted. He demanded from objects and figures that they show what he knew of them that established conventions had prevented him from stating. ${ }^{98}$ The metaphorical model of Cubism is the diagram: the diagram being a visible, symbolic representation of invisible processes, forces, structures. Like science, which was increasingly showing that nature was quite dissimilar to the way it is experienced, art now revealed the same about the object of perception. The picture could deny or even largely exclude observation of physical images, and it might be said to already exist within that picture as reflections of a mental process. This validated the Cubist enterprise which attempted to capture the immutable idea of an object, rather than rendering it by some personal interpretation of its changing and certainly deceptive appearance. ${ }^{99}$

After returning from La Rue-des-Bois, Picasso continued to paint other still lifes, focusing on a few substantial objects, like the apples and pears in Fruits et verre. ${ }^{100}$ As Rubin puts it, they seem to "temper the sophistication of Cézanne with the simplicity of Rousseau." They were an exaggeration of those found in the former, but stylized in the spirit of the latter. Pears, particularly, proved to have dramatic possibilities. Later he would vary their forms and their colors, often finding considerable similarities between the fruit and a human body. Already here, the darker and more unequivocally shaped pear balances somewhat tentatively in the shadow, while the two in the foreground are more assertive. The one closer to the viewer, in particular, shares human qualities as it lunges to the left but is pulled back by its stem which leans toward the other pear and the glass. ${ }^{102}$ It was in discussing this work that Rubin also noted Picasso's adoption of Cézanne's simulacrum of a bas-relief, where objects are modeled as if they did not have backs, that is, they do not create the illusion of space behind them. It is this type of accommodation of modeled forms to the two-dimensional surface, and their disposition in sequential groupings, that he now adopts. ${ }^{103}$

In late September, he met with Braque on his return from L'Estaque; ${ }^{104}$ the six landscapes he had brought back had been rejected by the Salon d'Automne. One felt that the forms in these paintings had not been suggested by those of particular landscapes but rather that he had imposed his own austere, angular, almost geometrical form of vision on the natural scenery. ${ }^{105}$ He would later say: "You see, the whole Renaissance tradition is antipathetic to me. The hard-and-fast rules of perspective which it succeeded in imposing on art were a ghastly mistake which it has taken four centuries to redress: Cézanne and, after him, Picasso and myself can take a lot of the credit for this. Scientific perspective is nothing but eye-fooling illusionism; it is simply a trick-a bad trick-which makes it impossible for an

\footnotetext{
98 Daix 1979, pp. 181-182.

99 Wadley 1970, p. 12; Kozloff 1973, pp. 6-8.

100 Fruits et verre. Paris. Fall/1908 [-1909]. Tempera on wood panel. 26,7 x $21.6 \mathrm{~cm}$. The Museum of Modern Art, NYC. (Inv 279.83). OPP.08:012.

101 Rubin 1972, p. 48.

102 Boggs 1992, p. 11.

103 Steinberg 2007, pp. 88-89.

104 Cousins \& Daix 1989, p. 358; Mahler 2015, p. 58.

105 Golding 1968, pp. 66-68.
} 
artist to convey a full experience of space, since it forces the objects in a picture to disappear away from the beholder instead of bringing them within his reach, as painting should."106 Matisse provided further details of those works: "He brought back from the south a Mediterranean landscape that represented a seaside village seen from above. In order to give more importance to the roofs, which were few, as they would be in a village, in order to let them stand out in the ensemble of the landscape, and at the same time develop the idea of humanity that they stood for, he had continued the signs that represented the roofs in the drawing on into the sky and had painted them throughout the sky. This is really the first picture constituting the origin of Cubism, and we considered it as something quite new, about which there were many discussions." 107 In fact the cubes from which the term derived, or rather the straight lines and the geometric simplifications they included, were merely a secondary effect, a surface manifestation of a research into pictorial space and how it could be made to coincide with the surface of the canvas to give a sensation of depth the fruits of which would only be collected much later. ${ }^{108}$

\section{Geometric Facets and Interlocking Shapes}

Aware of a certain complementarity between them, Picasso and Braque established a friendly partnership such as neither artist had ever experienced. Pablo quickly assimilated the way Georges had taken Cézanne further, so that the final version of Trois femmes shimmered with Cézannesque vibrations, ${ }^{109}$ the early African striations were now replaced with close-valued faceting of earth tones, green, and gray in a shallow bas-relief space. ${ }^{110}$ The superimposition of geometric facets on the interlocking shapes gives the impression that the picture as a whole forms a single, continuous surface molded into advancing and receding planes. ${ }^{111}$

Henceforth, it was the composition, by its contrasting rhythms, which revealed the structural element in the motif - always supposing that this is legible. In the artist's words, "the aim is not to reconstitute an anecdotal fact but to constitute a pictorial fact ... The subject is not the object; it is the new unity, the lyricism which stems entirely from the means employed."112 The experience of creating is neither prefigured nor confirmed by ideas gathered through perceptions of the world. Just as the eye does not mirror the world but fabricates one individual's image of reality, so the artist does not construct the object; he constructs his picture. Thus, picture making becomes virtually an autonomous activity, quite definitely and deliberately inscribing ideal energies and relations. As Picasso stated something similar: "When a form is realized it is there to live its own life."

When the Sixth Salon d'Automne opened from October 1 to November 8, the "acting jury" of the Salon, which included Matisse, had rejected Braque's paintings from L'Estaque. ${ }^{113}$ In

\footnotetext{
106 Richardson 1996, p. 97.

107 Cousins \& Daix 1989, p. 355

108 Daix 1979, p. 63.

109 Daix 2007, p. 27.

110 Baldassari, et al. 2002, p. 365; Fluegel 1980, p. 89.

111 Karmel 1993, pp. 34-35; Karmel 2007, p. 152; Steinberg 2007, pp. 75-89.

112 Kozloff 1973, pp. 9-12.

113 Ellderfield 1992, p. 18.
} 
reaction to the rejection, Kahnweiler offered to show a selection of his recent output in his gallery. ${ }^{114}$ The exhibition, organized in a big rush, took place November 9-28, and it featured twenty-seven works, including nineteen of the rejected landscapes, six still lifes of musical instruments and two nudes. ${ }^{115}$ In the catalogue preface, Apollinaire wrote: "There is room now for a more noble, more measured, more orderly, and more cultivated art. The future will tell how influential in this evolution were the magnificent example of a Cézanne, the solitary and determined toil of a Picasso, the unexpected meeting between a Matisse and a Derain, following upon the meeting between a Derain and a Vlaminck. Success has already rewarded the Picassos, the Matisses, the Derain, the de Vlamincks, the Frieszs, the Marquets, and the van Dongens. It will equally crown the works of a Marie Laurencin and a Braque ..."116 The show was much talked about. ${ }^{117}$ It would be the gallery's third and last (the first had featured Van Dongen, the second Camoin). ${ }^{118}$ The dealer would later explain: "I must say that after a certain point the few people interested in these painters-for there were five or six-came immediately to see the new paintings, and painters and art lovers unable to buy came too; but we never again exhibited publicly, which shows you the absolute contempt in which we held not only the critics, but also the general public." 119

Braque would gradually resolve the precarious tension of Cézanne's dual homage to optically perceived nature and intellectually conceived art, just as the description of surfaces became remote from reality, so, too, did the color take leave of perceived nature, tending toward an ever more severe monochromatic composition that allowed for the study of a new spatial structure without the interference of a complex chromatic organization. For all the apparent solidity of this new world of building blocks, there was something strangely unstable and shifting in its appearance. The ostensible cubes were to evolve into a pictorial language that rapidly discarded this preliminary reference to solid geometry and turned rather to a further exploration of an ever more ambiguous and fluctuating world. ${ }^{120}$

\section{Conclusion}

Of the period that followed, Braque later remarked: "Before long, Picasso and I had daily exchanges; we discussed and tested each other's ideas as they came to us, and we compared our respective works." Picasso would corroborate: "Almost every evening, either I went to Braque's studio or Braque came to mine. Each of us had to see what the other had done during the day. We criticized each other's work. A canvas wasn't finished unless both of us felt it was ... At that time our work was a kind of laboratory research from which every pretension or individual vanity was excluded."121 The ambition of the two painters at this time was to create art as an anonymous collective in which the hand of one could not be

\footnotetext{
114 Cousins \& Daix 1989, p. 355.

115 Cabanne 1979, p. 127; Fluegel 1980, p. 89; Cousins \& Elderfield 1992, p. 181; Monod-Fontaine 1994, p. 43; Richardson 1996, p. 102; Daemgen 2005, p. 19; Fraquelli, Cowling, Silver, Vasseur \& Bremner 2016, p. 161; Caruncho \& Fàbregas 2017, p. 70. Some incorrectly identify this as the first Picasso-Braque exhibition (Dagen 2009, p. 484).

116 Cousins \& Daix 1989, p. 356.

117 Baldassari 2007, p. 337.

118 Richardson 2007, pp. 101-102.

119 Kahnweiler 2003, p. 41.

120 Rosenblum 1976, p. 30.

121 Gilot \& Lake 1964, p. 77; Lebensztejn 2007, p. 42; Baldassari 2007, p. 337.
} 
distinguished from the hand of the other. Film might have been one of the models they followed since the medium was an ideal anonymous collective at the time. Films were often copied; if one succeeded, other producers and directors would pick up on it and do it again. Where there was one there are inevitably more; there was no one of a kind, and the audience loved seeing the same thing over and over in different versions. ${ }^{122}$ Their collaboration led to trading and sharing, but also to competition-daring one another to go just a little further.

A new lucidity was evolving in 1909, a pairing away of excess and a growing interest in the interplay of planes and volumes. ${ }^{123}$ "The aim is not to reconstitute an anecdotal fact but to constitute a pictorial fact," he stated. ${ }^{124}$ While Picasso would continue to implement a shamanistic approach to his art, the effect of his "climbing partner" on him was his abandonment of what remained of primitivist violence. He no longer needed to employ the paroxysmal expressiveness that had disconcerted his friend. In his still lifes of this period, his brushwork lightened to the point of becoming painterly penmanship. His experiments now concerned a technical quest for finesse rather than savageness. ${ }^{125}$

\section{References}

Baldassari, A. ed. (2007). Cubist Picasso. Paris: Réunion des Musées Nationaux / Flammarion.

Baldassari, A. et al. (2002). Matisse Picasso. London: Tate Publishing.

Baumann, F., Feilchenfeldt, W., \& Gassner, H. (2004). Cézanne and The Dawn of Modern Art. Hatje Cantz Publishers.

Boggs, J. S. et al. (1992). Picasso and Things. Cleveland: Cleveland Museum of Art.

Cabanne, P. (1979). Pablo Picasso: His Life and Times. New York: William Morrow \& Co.

Caruncho, D. R., \& Fàbregas, A. (2017). Biografía ilustrada de Pablo Picasso. Barcelona: Dos de Arte Ediciones.

Christie's. (1999). Twentieth Century Art. Auction catalogue 6146, June 30, London.

Christie's. (2007). Impressionist \& Modern Art Evening Sale. Auction catalogue 1900, November 6. New York.

Christie's. (2007). Impressionist \& Modern Art Works On Paper. Auction catalogue 1902, November 7. New York.

Christie's. (2013). A Dialogue Through Art: Works From The Jan Krugier Collection. Auction catalogue 3442, November 4. New York.

Cousins, J., \& Daix, P. (1989). “Chronology.” Picasso and Braque: Pioneering Cubism. pp. 335-452. Ed. by W. S. Rubin. New York: Museum of Modern Art Graphic Society.

\footnotetext{
122 Rose 2007, p. 82.

123 Schwartz 1971, p. 63.

124 Unger 2018, p. 373.

125 Daix 2007, p. 28.
} 
Cousins, J., \& Elderfield, J. (1992). “Chronology." Henri Matisse: A Retrospective. pp. 82-421. Ed. by J. Elderfield. New York: The Museum of Modern Art.

Cousins, J., \& Seckel, H. (1994). “Chronology.” Les Demoiselles d'Avignon. pp. 145-205. Ed. by W. S. Rubin \& H. Seckel. New York: Museum of Modern Art, Studies in Modern Art.

Cowling, E. (2002). Picasso: Style and Meaning. London; New York: Phaidon.

Cox, N. (2010). The Picasso Book. London: Tate Publishing.

Daemgen, A. (2005). "Picasso. Ein Leben." Pablo. Der private Picasso: Le Musée Picasso à Berlin. pp. 14-44. Ed. by A. Schneider \& A. Daemgen. München: Prestel.

Dagen, P. (2009). “Chronology.” Picasso. pp. 483-492. Ed. by P. Dagen. New York: The Monacelli Press.

Daix, P. (1965). Picasso. New York: Preager.

Daix, P. (2007). Pablo Picasso. Paris: Tallandier.

Daix, P., \& Rosselet, J. (1979). Picasso: The Cubist Years, 1907-1916: A Catalogue Raisonné of the Paintings \& Related Works. Boston: New York Graphic Society.

Elderfield, J., ed. (1992). Henri Matisse: A Retrospective. New York: The Museum of Modern Art.

Fluegel, J. (1980). "Chronology." Pablo Picasso. A Retrospective. pp. 16-421. Ed. by W. S. Rubin. New York: the Museum of Modern Art.

Franck, D. (2001). Bohemian Paris: Picasso, Modigliani, Matisse, and the Birth of Modern Art. New York: Grove Press.

Fraquelli, S. et al. (2016). "Chronology." Picasso: The Great War, Experimentation, and Change. pp 161-163. Ed. by S. Fraquelli, E. Cowling, K. Silver, D. H. Vasseur, A. Bremner. New York: Scala Arts Publishers Inc.

Gilot, F., \& Lake, C. 1964). Life with Picasso. New York: McGraw-Hill.

Golding, J. (1968). Cubism: A History and an Analysis 1907-1914. New York: Harper \& Row.

Gray, C. (1953). Cubist Aesthetic Theories. Baltimore: The Johns Hopkins Press.

Kahnweiler, D.-H. (1949). The Rise of Cubism. New York: Wittenborn, Schultz.

Kahnweiler, D.-H. (2003). My Galleries and Painters. Boston: MFA Publications.

Karmel, P. (1993). Picasso's Laboratory: The Role of his Drawings in the Development of Cubism, 1910-1914. Ph.D. Dissertation. New York University. Ann Arbor, Michigan: University Microfilms International.

Karmel, P. (2007). "Le Laboratoire Central." Cubist Picasso. pp. 149-163. Ed. by A. Baldassari. Paris: Flammarion. 
Kozloff, M. (1973). Cubism/Futurism. New York: Harper \& Row.

Krauss, R. (1998). The Picasso Papers. New York: Farrar Straus \& Giroux.

Lebensztejn, J. (2007). "Periods: Cubism in Its Day.” Cubist Picasso. pp. 31-53. Ed. by A. Baldassari. Paris: Flammarion.

Mahler, L. (2015). "Selected Exhibitions, 1910-1967.” Picasso Sculpture. pp. 304-311. Ed. by A. Temkin \& A. Umland. New York: The Museum of Modern Art, New York.

Mallen, E. ed. (2021). Online Picasso Project (OPP). Sam Houston State University. Retrieved from http://picasso.shsu.edu.

Monod-Fontaine, I. (1994). "Biographie." Die Sammlung Kahnweiler: Von Gris, Braque, Léger und Klee bis Picasso. pp. 40-66. Ed. by H. A. Peters. Munich: Prestel Verlag.

O’Brian, P. (1994). Pablo Picasso. A Biography. New York: W.W. Norton \& Company.

Olivier, F. (2001). Loving Picasso: The Private Journal of Fernande Olivier. New York: Harry N. Abrams.

Palau i Fabre, J. (1990). Picasso: Cubism (1907-1917). Köln: Könemann.

Richardson, J. (1991). A Life of Picasso. Volume I: The Prodigy, 1881-1906. New York: Random House.

Richardson, J. (1996). A Life of Picasso. Volume II: The Painter of Modern Life, 19071917. New York: Random House.

Richardson, J. (2007). A Life of Picasso. Volume III: The Triumphant Years, 1917-1932. New York: Alfred A. Knopf.

Roe, S. (2015). In Montmartre: Picasso, Matisse and Modernism in Paris 1900-1910. New York: Penguin Press.

Rose, B. (2007). "Picasso, Braque and Early Film in Cubism." Picasso, Braque and Early Film in Cubism. pp. 35-141. Ed. by B. B. Rose. New York: PaceWildenstein.

Rosenblum, R. (1967). "Picasso: At the Philadelphia Museum of Art." Philadelphia Museum of Art Bulletin. Vol. 62, No. 292, Picasso. (Jan.-Mar.). pp. 167-203. https://doi.org/10.2307/3795176

Rosenblum, R. (1976). Cubism \& Twentieth Century Art. New York: Harry N. Abrams.

Rubin, W. S. et al. (1972). Picasso in the Collection of the Museum of Modern Art. New York: Museum of Modern Art.

Schwartz, P. W. (1971). Cubism. New York: Praeger.

Seckel, H. (1996). Musée Picasso: Visitor’s Guide. Paris: Réunion des Musées Nationaux.

Sotheby's. (2014). Impressionist \& Modern Art Evening Sale. Auction catalogue N09219, 11/04/14. New York. 
Stein, G. (1961), The Autobiography of Alice B. Toklas. New York: Vintage Books.

Steinberg, L. (2007). "Resisting Cézanne: Picasso's 'Three Women." Cubist Picasso. pp. 71-101. Ed. by A. Baldassari. Paris: Flammarion.

Torras, M. (2002). “Cronología / Chronology.” Picasso joven - Young Picasso. pp. 87-106. ed. by M. T. Ocaña, M. Torras, et al. A Coruña: Fundación Pedro Barrie de la Maza.

Unger, M. J. (2018). Picasso and the Painting That Shocked the World. New York: Simon \& Schuster.

Vallentin, A. (1963). Picasso. Garden City, N.Y: Doubleday \& Co.

Wadley, N. (1970). Cubism. New York: The Hamlyn Publishing Group.

\section{Copyrights}

Copyright for this article is retained by the author(s), with first publication rights granted to the journal.

This is an open-access article distributed under the terms and conditions of the Creative Commons Attribution license (http://creativecommons.org/licenses/by/4.0/) 